\title{
OBITUARY
}

\section{Prof. G. O. Sherrard}

WITH the death in September last of Prof. G. O. Sherrard, affectionately known to all as 'G. O.', horticulture in general and Irish horticulture in particular has lost a most distinguished devoted scholar. $\mathrm{He}$ was born seventy-six years ago on the family estate near Cork City, As a boy, he had two great ambitions, to become a gardener and to teach. His father appeared to have different ideas and sent him to Westward Ho, Old United Services College and later to Woolwich Military Academy, where he received his commission.

A wish to travel prompted Sherrard to volunteer for foreign service. He was sent to Gibraltar, where he contracted Malta fever. Home on sick leave and advised to adopt an outdoor life, he naturally and fortunately chose horticulture. The soldier turned gardener now trained at Albert College, and afterwards entered the Royal College of Science, Dublin, on a scholarship, where in 1910 he obtained the A.R.C.Sc.I.

After a short period as a teacher of rural science in Co. Kildare, he was awarded a scholarship by the Development Commissioners and went to the John Innes Horticultural Institution to study genetics and plant breeding under Prof. W. Bateson. He interrupted study for active service in the First World War, reached captain's rank and was awarded the Military Cross.

From war to study again, and then back to Ireland as lecturer in horticulture in the Royal College of Science. At the foundation of the Faculty of Agriculture in 1926 he transferred to University College, Dublin, where in 1940 he became professor of horticulture-Ireland's first horticultural professor.

The Royal Horticultural Society of Ireland awarded him its Gold Medal for conspicuous service to Irish horticulture in 1941, and in 1953 the Horticultural Education Association elected him as president, the first and only Irishman to be so honoured. He was an active member of the council of the Royal Horti- cultural Society of Ireland and was president of that Society during 1955-58.

Prof. Sherrard was a wonderful teacher and a fine research worker, who contributed nobly to Irish prosperity. In his life-time, he witnessed a complete change in the horticultural pattern-a transition from the big estate garden to that of the suburban villa, and the remarkable development of commercial horticulture within the past quarter of a century. Quick to perceive the change, and adequate to cope with the changing requirements, he provided trained personnel for advisory, research and administrative posts. He was an inspiration and guide at a very critical period.

Although Sherrard's name as a research worker tends to be linked almost exclusively with his wonderful pioneering work on Brussels sprouts, he found time during a very busy life to publish papers dealing with the nutritional, breeding and cropping aspects of vegetables, fruits and glasshouse crops. He gave many public lectures, wrote a book on fruit and vegetable growing, contributed weekly press articles on popular gardening, and through friendly informative weekly gardening talks from Radio Eireann became the doyen of Irish broadcasting.

His outstanding work has been concerned with the breeding and improvement of commercial strains of Brussels sprouts, on which he embarked in 1924. Out of the chaos of that time he created a high order, and as monuments to his skill, patience and abiding interest he has left behind such wonderful varieties as Glasnevin Supreme, Irish Elegance and the freezer Irish Glacier. In whatever clime this crop is grown, Sherrard's name will be remembered and honoured.

Modesty and simplicity were innate characteristics of the man who put Glasnevin and Ireland before self-exaltation. An octogenarian, thinking aloud at his graveside, summed up what all of us who knew him felt in our hearts-" "he was a great man and a thorough gentleman". We are the poorer for his passing, but take heart from his fine example.

E. Clarke

\section{NEWS and VIEWS}

General Post Office Engineering Appointments:

The Postmaster General has approved the appointment of Mr. A. H. Mumford, deputy engineerin-chief, to be engineer-in-chief in succession to Sir Lionel H. Harris, who is retiring on January 31. Capt. C. F. Booth and Mr. D. A. Barron, both of whom are assistant engineers-in-chief, have been appointed deputy engineers-in-chief.

Sir Lionel Harris, K.B.E.

Srr Lrontl Harris joined the Post Office Research Branch at Dollis Hill in 1922, having spent four years with Signals in the Australian Imperial Forces and graduated in the University of London from the City and Guilds Engineering College. He was superintending engineer of the North Midland District of the Post Office on the outbreak of war in 1939 , when he left to join his Territorial Army unit. After Dunkirk he successively commanded G.H.Q. Signals, was chief signal officer, Lines of Communication; and finally for two years chief of General Fisenhower's Telecommunications Section. After the War he became for four yoars director of the Post Office in Scotland, then controller of research and finally (in October 1954) engineer-in-chief.

Mr. A. H. Mumford, O.B.E.

Mr. A. H. MUMFond was born in London in 1903 and was educated at Bancroft's School and the University of London. He entered the Post Office in 1924 as an assistant engineer; before very long he joined the Dollis Hill Research Laboratory, where he 